\title{
Penyesuaian Fungsi Deret Fourier untuk Karakteristik Pola Curah Hujan di Kota Pontianak
}

\author{
Andi Ihwan \\ Jurusan Fisika, FMIPA Universitas Tanjungpura, Pontianak, \\ e-mail: iwankonjo@yahoo.com
}

\begin{abstract}
Abstrak
Secara umum karakteristik curah hujan bulanan di Indonesia menunjukkan adanya pola hubungan dengan frekuensi revolusi bumi yang menyebabkan spektrum gelombang tidak bisa dianggap berdiri sendiri. Hal ini membuat fluktuasi curah hujan terhadap waktu merupakan fungsi gelombang priodik tak-harmonik dimana fungsi gelombang tersebut adalah superposisi gelombang yang harmonik. Karakteristik curah hujan yang merupakan superposisi gelombang tersebut dapat didekati dengan analisis deret Fourier. Hasil simulasi menggunakan metode leastsquare non linier menunjukkan bahwa pola curah hujan bulanan di Kota Pontianak dapat didekati dengan analisis deret Fourier pada orde ke-8 dengan tingkat kesesuaian di atas 70\%.
\end{abstract}

Kata kunci : deret Fourier, Gauss Newton, curah hujan, superposisi gelombang.

\section{Perndahuluan}

Fenomena iklim/cuaca di Indonesia sangat kompleks dimana banyak parameter yang dapat mempengaruhi iklim tersebut, baik jangka pendek maupun panjang diantaranya adalah fenomena El Nino, La Nina di Samudera Pasifik Equator, Dipole Mode di Samudera Hindia, serta aktivitas matahari. Oleh karena itu tidaklah mudah membuat prediksi iklim/cuaca terutama untuk jangka waktu yang panjang (Ramage, 1971 Tjasjono, 2004)

Hasil analisis periodik dan frekuensi dari data time series curah hujan bulanan beberapa Kota di Kalimantan Barat menggunakan metode FFT menunjukkan bahwa pola curah hujan bulanan untuk Kota Pontianak berbeda dengan kota-kota lainnya, Kota Pontianak magnitude maksimum terjadi yang pada periode 6 bulanan sedangkan untuk kota yang lainnya pada periode 12 bulanan (Ihwan, 2012). Hal ini menunjukkan bahwa puncak curah hujan di Kota Pontianak terjadi dua kali dalam setahun (pola equatorial), yakni terjadi pada bulan Maret dan September. Jika dikaitkan dengan revolusi bumi (gerak semu tahunan matahari) maka matahari lebih dekat dengan equator pada bulan Maret dan September sehingga paparan radiasi matahari lebih tinggi di dua bulan tersebut dibandingkan dengan bulan-bulan lainnya.

Karena tingkat curah hujan bulanan bersifat non-linier (berfluktuasi terhadap waktu) maka untuk mengetahui karakteristiknya dapat didekati dengan menggunakan model inversi diantaranya dengan menggunakan metode Gauss Newton. Metode ini juga disebut metode linierisasi yang menggunakan expansi deret Taylor untuk menghampiri model regresi non-linier menjadi bentuk linier. Dalam model ini, data curah hujan akan dipelajari historistorisnya untuk jangka waktu yang panjang (puluhan tahun kebelakang), serta sifat kedinamisan perubahan yang terjadi hingga akhirnya menemukan faktor - faktor penyebab perubahan tersebut.

\section{Landasan Teori}

\subsection{Deret Fourier}

Sebuah gelombang periodik takharmonik terjadi akibat superposisi antara dua gelombang atau lebih yang memiliki amplitudo dan frekuensi yang berbeda. Fisikawan Prancis Jean Baptiste Joseph, Baron de Fourier mengatakan sebuah fungsi dengan frekuensi, boleh jadi merupakan perpaduan dari beberapa fungsi harmonik. Teori ini kemudian dikenal dengan deret Fourier yang direpresentasikan dalam bentuk matematika sebagai berikut

$$
\begin{gathered}
f(t)=a_{0}+\sum_{i=1}^{n}\left(a_{i} \cos (n 2 \pi f t)\right)+ \\
\sum_{i=1}^{n}\left(b_{i} \sin (n 2 \pi f t)\right)
\end{gathered}
$$


$a_{0}, a_{i}$ dan $b_{i}$ disebut koefisien fourier

\subsection{Bentuk Non-linier least square}

Metode least square adalah suatu metode untuk menghitung suatu kurva sedimikian hingga meminimumkan ralat penyesuaian di titik - titik data tersebut. Metode least square menggunakan pendekatan geometris. Secara geometris, garis yang paling mewakili sebaran sampel adalah garis yang mempunyai simpangan minimum, atau error terkecil dari pencarian data. Untuk memudahkan perhitungan, jarak aslinya berupa harga mutlak dari error, $\left|e_{i}\right|$ diganti dengan kuadrat error tersebut, yaitu $e^{2}$.

Secara umum model non-linier adalah sebagai berikut :

Dimana:

$$
\begin{array}{r}
y=\left(y_{1}, y_{2}, \ldots, y_{T}\right), f(X, \beta)=\left[f\left(x_{1}, \beta\right),\right. \text { dan } \\
\frac{\partial S}{\partial \beta}=-2\left[\frac{\partial f(X, \beta)^{\prime}}{\partial \beta}\right][y-f(X, \beta)]=0
\end{array}
$$

$\left.f\left(x_{2}, \beta\right), \ldots, f\left(x_{T}, \beta\right)\right]$, serta $X=\left(x_{1}, x_{2}, \ldots, x_{T}\right)$, adalah vektor independen variabel dan $e=$ $\left(e_{1}, e_{2}, \ldots, e_{\mathrm{T}}\right)$ adalah random error. Parameter yang tidak diketahui diperoleh melalui optimasi objective function. Dengan spesifikasi tersebut dapat digunakan least square estimation, yaitu residual sum of squares function adalah :

$$
S=e^{\prime} e=[y-f(X, \beta)][y-f(X, \beta)]
$$

Dengan meminimumkan objective function (S) tersebut maka akan dilakukan penaksiran parameter $\beta$. First order condition atau normal equation untuk nilai minimum objective function adalah :

$$
\frac{\partial S}{\partial \beta}=-2\left[\frac{\partial f(X, \beta)^{\prime}}{\partial \beta}\right][y-f(X, \beta)]=0
$$

dengan $\frac{\partial f(X, \beta)}{\partial \beta}$ ' adalah matrik derivatif. Bila fungsi $f(X, \beta)$ adalah non-linier dalam arti kata koefisiennya, maka menaksir nilai $\beta$ yang minimumkan objective function tidak dapat diperoleh secara langsung sebagaimana model yang linier (Howison, 2005).

\subsection{Metode Gauss-Newton}

Apabila dilakukan $m$ eksperimen, maka ada $\mathrm{m}$ error yaitu $r_{1}, r_{2}, \ldots r_{m}$ yang tergantung pada variabel $\beta_{1}, \beta_{2}, \ldots \beta_{n}$, dengan $\mathrm{m} \geq \mathrm{n}$. Error ini merupakan selisih antara hasil eksperimen (yang dinotasikan dengan Y) dengan penaksir Y (dinotasikan Ŷ). Fungsi jumlah kuadrat error adalah :

$$
S(\beta)=\sum_{i=1}^{m}\left(Y_{i}-Y_{i}\right)^{2}=\sum_{i=1}^{m} r_{i}^{2}(\beta)
$$

Yang ditaksir adalah vekor $\beta=\left(\beta_{1}, \beta_{2}, \ldots \beta_{n}\right)$. Proses iterasi dimulai dengan memberikan nilai awal untuk $\beta^{\circ}=\left(\beta_{1}, \beta_{2}, \ldots \beta_{\mathrm{n}}\right)^{\mathrm{o}}$, dan nilai penaksir selanjutnya $\beta^{(1)}=\beta^{(0)}+\Delta$, secara umum iterasi Gauss-Newton dinyatakan sebagai berikut :

$$
\beta^{(s+1)}=\beta^{(s)}+\Delta
$$

Vektor $\Delta$ merupakan solusi persamaan normal (metode penaksiran kuadrat terkecil atau least square) berikut :

$$
\left(\mathbf{J}_{r}{ }^{T} \mathbf{J}_{r}\right) \Delta=\mathbf{J}_{r}{ }^{T} \mathbf{r}
$$

Dimana $\beta^{(1)}$ adalah Nilai dugaan awal parameter, $\beta^{(\mathrm{s}+1)}$ adalah Parameter yang akan ditaksir, $r$ adalah Selisih antara pengukuran dan prediksi, $\mathbf{J}_{\mathrm{r}}$ adalah Matriks Jacobian serta $\mathbf{J}_{\mathrm{r}}$ berukuran $m \quad x \quad n$ berdasarkan fungsi $r_{i}(\beta)=y_{i}-f\left(x_{i}, \beta\right)$ (Grandis, 2003).

$$
\mathbf{J}_{r}=\left[\begin{array}{c|ccc|c}
\frac{\partial r}{\partial \beta_{1}} \beta_{\beta()_{, x} 1} & & \cdots & \frac{\partial r}{\partial \beta_{n}} & \\
\beta(s)_{, x_{1}} \\
\vdots & \vdots & \ddots & \vdots \\
\left.\frac{\partial r}{\partial \beta_{1}}\right|_{\beta(s), x_{m}} & & \cdots & \frac{\partial r}{\partial \beta_{n}} & \beta^{(s)}, x_{m}
\end{array}\right]
$$

\section{Metodologi}

Data yang digunakan dalam makalah ini adalah data curah hujan bulanan Kota Pontianak selama 15 tahun (1996 - 2011). Estimasi curah hujan bulanan Kota Pontianak akan dihitung dengan menggunakan metode Gauss-Newton. Pada proses estimasi, parameter model diinput ke dalam model. Estimasi akan diterima jika korelasi antara data observasi dengan data model berhubungan kuat (minimal 0,6). 


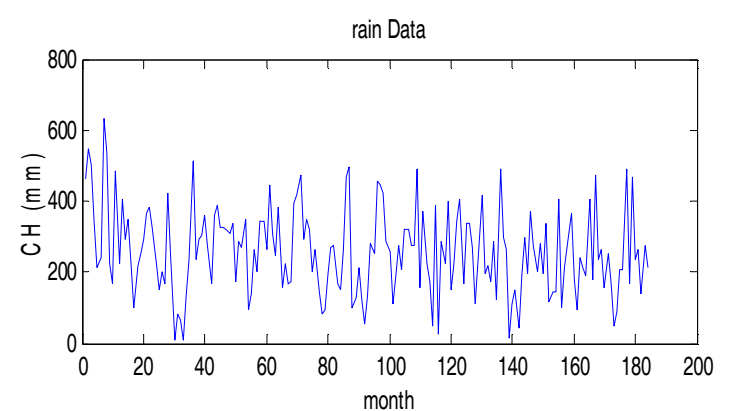

Gambar 1. Contoh data curah hujan bulanan Kota Pontianak selama 15 tahun (sumber data BMKG Pontianak)

Model Gauss-Newton tersebut dianalisis dengan least qquare untuk menghasilkan kurva fitting yang bersesuaian. Fungsi yang digunakan sebagai kurva fitting diambil dari persamaan yang digunakan dalam pemodelan adalah fungsi matematika yakni deret fourier (Persamaan (1)). (Howison, 2005).

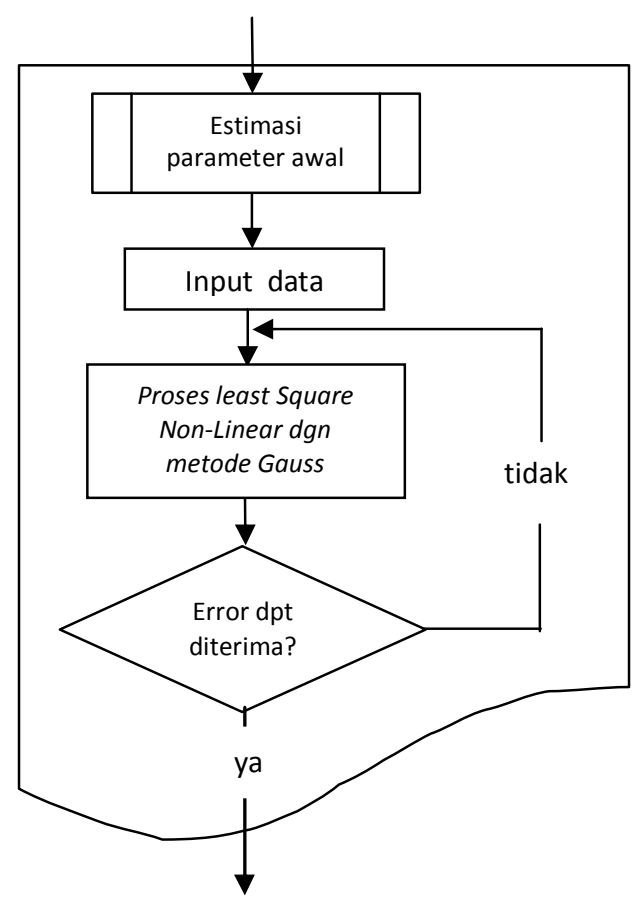

Gambar 2. Alur kerja analisis model Least Square non-Linier

\section{Hasil Dan Pembahasan}

Tahap awal yang dilakukan adalah menginisiasi Initial value ini diperoleh melalui pencocokan kurva (curve fitting). Pada saat mencocokan titik data observasi dengan kurva fungsi deret Fourier maka secara otomatis akan ditampilkan nilai initial value. Selain menggunakan pencocokan kurva initial value juga dapat diperoleh secara try and error.

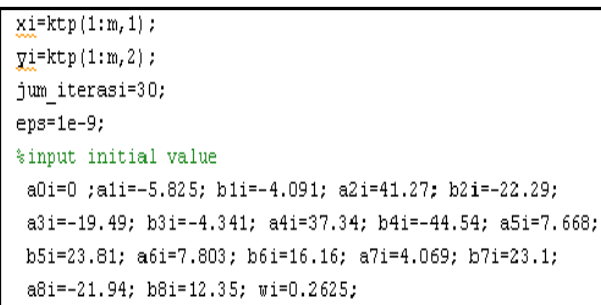

Tampilan di atas adalah contoh initial value untuk koefisien Fourier 8 orde yang diinput pada program utama. Dari cuplikan program di atas terdapat 18 initial value yaitu a0i, a1i, b1i, a2i, b2i, a3i, b3i, a4i, b4i, a5i, b5i, a6i, b6i, a7i, b7i, a8i, b8i, dan wi.

Tahap berikutnya yang dilakukan adalah estimasi dengan metode GaussNewton. Metode ini bertujuan untuk meminimumkan fungsi jumlah kuadrat error. Matriks Jacobi yang digunakan merupakan matriks derivatif yang diperoleh dengan mendiferensialkan fungsi deret Fourier terhadap masing-masing parameter yang ada pada fungsi tersebut.

Dari hasil simulasi diperoleh bahwa orde fungsi deret Fourier mampu memodelkan data dengan baik pada orde-8. Nilai initial value yang cocok untuk pola curah hujan bulanan Kota Pontianak adalah sebagai berikut : a0i $=254,8$; a1 $\mathrm{i}=43,09$; b1i = 38,17; a2i = 10,41; b2i = -23,43; a3i = 2,19; b3i = 25,29; a4i = -23,39; b4i = 4,66; a5i = 11,54; b5i = -19,86; a6i = -9,53; b6i = 1,$67 ;$ a $7 \mathrm{i}=-15,32 ; \mathrm{b} 7 \mathrm{i}=-333,48 ; \mathrm{a} 8 \mathrm{i}=$ 23,26; b8i $=-15,12$; wi $=0,53$. Karena setiap wilayah pengamatan mempunyai ciri pola curah hujan tersendiri sehingga jika ingin memodelkan curah hujan wilayah lain, maka nilai initial value ini harus dimodifikasi lagi.

Initial value tersebut kemudian diinput ke dalam Persamaan (1) untuk menghasilkan data model seperti yang diperlihatkan pada Gambar 3 di bawah ini. 


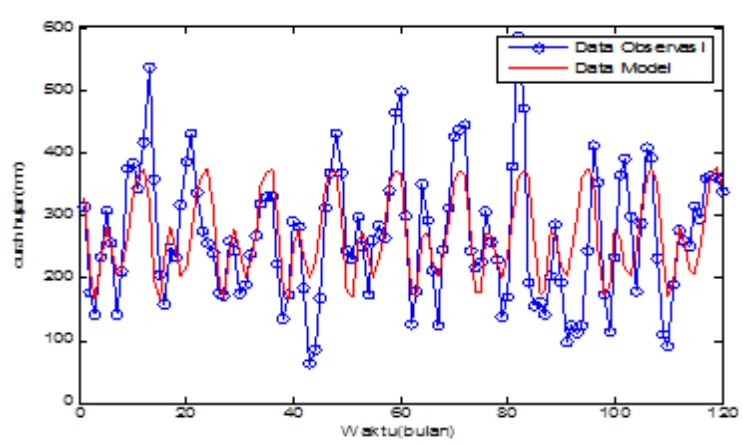

Gambar 3. Grafik curah hujan bulanan observasi dan curah hujan hasil model Kota Pontianak

Gambar 3 di atas merupakan grafik curah hujan bulanan Kota Pontianak berdasarkan data observasi dan data model. Secara umum data model yang dihasilkan mampu menghasilkan pola yang menyerupai pola data observasi walaupun untuk beberapa titik data model yang dihasilkan belum mampu mendekati nilai data observasi secara maksimal. Data model ini kemudian dikorelasikan dengan data observasi untuk mengetahui tingkat hubungan diantara keduanya. Koefisien korelasinya $70 \%$ hal ini menunjukkan bahwa fungsi gelombang yang dihasilkan dari deret fourier orde- 8 , telah berhasil dengan baik mengikuti pola curah hujan bulanan Kota Pontianak. Dengan nilai RMSE 104,84.

\section{Kesimpulan}

Pola curah hujan Kota Pontianak terbukti dapat didekati dengan fungsi superposisi beberapa gelombang harmonik. Superposisi dari gelombang harmonik ini menghasilkan gelombang priodik takharmonik dimana parameter amplitudo tiap sukunya ditentukan dari metode least square menggunakan algoritma GaussNewton.

Korelasi antara data curah hujan observasi dengan fungsi gelombang yang dihasilkan cukup kuat. Nilai korelasi bersesuaian dengan koefisien korelasi 70\%.

\section{Daftar Pustaka}

Ramage, C.S., 1971, Monsoon Meteorology, Academic Press Inc., International Geophysics Series, Vol. 15.

Tjasjono, B, 2004, Klimatologi, Edisi Kedua, Penerbit Itb, Bandung.

Ihwan, A., 2012, Algorithma Fast Fourier Trasform (FFT) Untuk Analisis Pola Curah Hujan Di Kalimantan Barat, Jurnal Aplikasi Fisika, Unhalu Vol. 8 No. 1 Hal. 60 - 65 .

Grandis, H., 2003, Inversi Geofisika, Edisi Ke1, Program Studi Geofisika Fakultas Ilmu Kebumian dan Teknologi Mineral, ITB, Bandung.

Howison, S., Crighton (Deceased), C. G., Ablowitz, M. J., Davis, S. H.; Hinch, E. J., Iserles, A.' Ockendon, J., Olver, P. J., 2005, Practical Applied Mathematics: Modelling, Analysis, Approximation, Cambridge University Press. 